\title{
Rational Development of Structurally Ordered Platinum Ternary Intermetallic Electrocatalysts for Oxygen Reduction Reaction
}

\author{
Zhongxiang Wang, Xiaozhang Yao, Yongqiang Kang, Dongsheng Xia and Lin Gan * \\ Division of Energy and Environment, Graduate School at Shenzhen, Tsinghua University, \\ Shenzhen 518055, China \\ * Correspondence: lgan@sz.tsinghua.edu.cn; Tel.: +86-755-26032622
}

Received: 16 May 2019; Accepted: 20 June 2019; Published: 26 June 2019

check for updates

\begin{abstract}
Structurally ordered intermetallic structure is an efficient catalyst design strategy to significantly improve the catalytic performance of $\mathrm{Pt}$ alloy electrocatalysts for oxygen reduction reaction in fuel cells. However, a high structural ordering degree generally relies on high-temperature annealing, which results in detrimental catalyst particle sintering. Herein, we reveal that the incompatibility between high ordering degree and minimum particle sintering during thermal annealing can be resolved through rational development of structurally ordered Pt ternary alloys. Ordering transformation mediated by high-temperature annealing of three representative $\mathrm{Pt}$ ternary alloys ( $\mathrm{Pt}-\mathrm{Fe}-\mathrm{Co}, \mathrm{Pt}-\mathrm{Ni}-\mathrm{Co}$ and $\mathrm{Pt}-\mathrm{Fe}-\mathrm{Ni}$ ) at a similar Pt composition was systematically studied. It was found that Fe can significantly promote the structural ordering due to a faster atomic diffusion, whereas Co can effectively inhibit the particle sintering. As a result of the synergy between $\mathrm{Co}$ and Fe, the ordered PtCoFe catalyst exhibited the highest ordering degree after thermal annealing at $600{ }^{\circ} \mathrm{C}$ with the minimum nanoparticle growth, leading to the highest catalytic activity $\left(0.65 \mathrm{~A} / \mathrm{mg}_{\mathrm{Pt}}\right.$ at $0.9 \mathrm{~V}, 4$ times that of pure Pt catalyst) and best stability (16\% drop after 10,000 potential cycles). This study provides important clues for the rational design of high-performance structurally ordered ternary Pt alloys.
\end{abstract}

Keywords: electrocatalysis; oxygen reduction reaction; ternary alloys; ordered intermetallics

\section{Introduction}

The slow kinetics of oxygen reduction reaction (ORR) is a major bottleneck for the development of proton exchange membrane fuel cells (PEMFCs). Although platinum (Pt) is generally considered to possess the highest ORR catalytic activity among pure metals [1], the scarcity and high cost greatly restrict its large-scale utilization. Alloying $\mathrm{Pt}$ with a transition metal ( $\mathrm{Fe}, \mathrm{Co}, \mathrm{Ni}, \mathrm{Cu}, \mathrm{etc}$.) has been demonstrated an effective approach to increase the catalytic activity and thus reduce the usage of $\mathrm{Pt}$ [2], due to the electronic and/or strain effect between the non-noble transition metals and $\mathrm{Pt}$ [3-5]. However, under the acidic ORR environment, the nonprecious metals in Pt alloys will be continuously leached, leading to substantial activity degradation during long-term electrocatalysis [6,7]. Recently, compared to conventional disordered Pt alloys, structurally ordered Pt intermetallics have shown much enhanced activity and stability towards ORR due to a higher antidissolution capability of nonprecious metals [8-12]. The formation of structurally ordered intermetallics usually relies on the thermal annealing of the disordered counterparts at high temperatures (usually above $600{ }^{\circ} \mathrm{C}$ ), which, however, could generally result in a detrimental particle sintering effect and thus discounted catalytic performance. To suppress the particle sintering during thermal annealing, tedious processes such as protection by $\mathrm{KCl}[13]$, oxide [8,14], or carbon [12,15], have been developed yet are difficult to be scaled up. 
Compared to binary alloys, ternary alloys generally allow a greater flexibility in adjusting the Pt electronic structure and catalytic properties [16,17]. Recent experiments have also found that $\mathrm{Pt}$ ternary alloys may be easier to achieve ordering transition compared to Pt binary alloys. For example, adding a small amount of $\mathrm{Cu}$ can effectively lower the temperature needed for structurally ordering of $\mathrm{Pt}-\mathrm{Fe}$ alloy $[18,19]$. Cobalt (Co) was also found to enhance the ordering of a $\mathrm{Pt}(\mathrm{NiCo})$ alloy compared to PtNi alloy [20]. As a result, ordered Pt ternary ORR catalysts have drawn considerable interest recently $[18,20-23]$. These studies suggest that it is possible to achieve structural ordering of Pt ternary alloys at relatively lower temperatures without the use of tedious surface coating strategies, thus opening a new way to suppress the associated particle sintering at high temperatures. However, the specific roles of the different alloying transition metals during the ordering transformation of $\mathrm{Pt}$ ternary alloys are still poorly understood.

To rationally develop ordered Pt ternary intermetallics as durably active ORR electrocatalysts, we present here a systematic and comparative study of the ordering transformation and ORR activity/stability of three representative $\mathrm{Pt}$ ternary alloy catalysts ( $\mathrm{Pt}-\mathrm{Fe}-\mathrm{Co}, \mathrm{Pt}-\mathrm{Co}-\mathrm{Ni}$ and $\mathrm{Pt}-\mathrm{Fe}-\mathrm{Ni}$ ) with a similar Pt atomic content of $\sim 40 \%$. With the aid of X-ray diffraction and (high-resolution) transmission electron microscopy (TEM), we focused on the particle size distributions and ordered/disordered structures of the three ternary catalysts after annealing at $600{ }^{\circ} \mathrm{C}$, in an effort to disclose the roles of different alloying metals. The compositional core-shell structures formed by leaching of surface non-noble metals during ORR electrocatalysis were also probed by electron energy loss spectroscopy (EELS) mapping, aiming to provide some clues on the antidissolution capabilities of different non-noble metals. Based on these studies, we develop a structurally ordered $\mathrm{Pt}-\mathrm{Fe}-\mathrm{Co}$ intermetallic catalyst with both high ordering degree and minimum particle sintering, showing the highest activity and stability among the different $\mathrm{Pt}$ ternary catalysts.

\section{Results and Discussion}

The three ternary alloy nanoparticles (NPs) with Pt atomic content of $\sim 40 \%$ (referred to as PtMN, $\mathrm{M}, \mathrm{N}=\mathrm{Fe}, \mathrm{Co}, \mathrm{Ni}$, etc.) were synthesized by using organic solution phase reduction methods (see Experimental section for details), and then supported on high surface area carbon (Vulcan XC). Their energy-dispersive spectrometer (EDS) compositions are $\mathrm{Pt}_{44} \mathrm{Co}_{36} \mathrm{Fe}_{20}, \mathrm{Pt}_{37} \mathrm{Fe}_{52} \mathrm{Ni}_{11}$, and $\mathrm{Pt}_{39} \mathrm{Ni}_{32} \mathrm{Co}_{29}$, and the compositions obtained from inductively coupled plasma mass spectrometer (ICP-MS) are $\mathrm{Pt}_{41} \mathrm{Co}_{40} \mathrm{Fe}_{19}, \mathrm{Pt}_{36} \mathrm{Fe}_{48} \mathrm{Ni}_{16}$, and $\mathrm{Pt}_{35} \mathrm{Ni}_{40} \mathrm{Co}_{25}$, respectively. The realistic Pt contents in the catalysts were also determined by ICP (see Table S1). The supported catalysts were firstly heated in air at $180^{\circ} \mathrm{C}$ to remove residual surfactants used in the nanoparticle synthesis, and then annealed at $400{ }^{\circ} \mathrm{C}$ in $\mathrm{Ar} / 4 \% \mathrm{H}_{2}$ for $4 \mathrm{~h}$ to obtain disordered Pt ternary alloy catalysts, which were designated as PtMN-H400. The disordered nanoparticle catalysts were further annealed at 600 or $800{ }^{\circ} \mathrm{C}$ in an $\mathrm{Ar} / 4 \%$ $\mathrm{H}_{2}$ atmosphere and then naturally cooled down to induce structural ordering (denoted as PtMN-H600 or PtMN-H800).

The morphology of the ternary alloy catalysts after heat treatment at 400 and $600{ }^{\circ} \mathrm{C}$ and their X-ray diffraction (XRD) patterns are shown in Figure 1. The XRD profiles in Figure 1a show that the as-prepared PtNiCo nanoparticles have two phases: a Pt-richer phase ( $\{111\}$ peak at $\left.41.8^{\circ}\right)$ and a Co-richer $\left(\{111\}\right.$ peak at $\left.44.2^{\circ}\right)$. After annealing at $600{ }^{\circ} \mathrm{C}$, the $\mathrm{PtNiCo}-\mathrm{H} 600$ catalyst shows a weak $\{110\}$ superlattice peak at $33.3^{\circ}$, indicating a slight ordering transformation. After annealing at a higher temperature $\left(800^{\circ} \mathrm{C}\right)$ for $4 \mathrm{~h}$ and longer time $(12 \mathrm{~h})$, the diffraction from Co-rich phase greatly weakened, indicating decreased lattice parameter (Table S2), and thus increased alloying degree of $\mathrm{PtNiCo}$. However, the obtained PtNiCo-H800 became completely disordered. For the PtCoFe and PtFeNi catalysts, a disordered single phase after annealing at $400{ }^{\circ} \mathrm{C}$ was revealed from the XRD patterns, yet both can achieve obvious ordering transformation and a higher extent of alloying (Table S2) after annealing at $600{ }^{\circ} \mathrm{C}$ (Figure 1d,g) with a higher ordering degree compared to PtNiCo-H600 catalyst, judged from much higher relative intensity of the $\{110\}$ diffraction peak. 

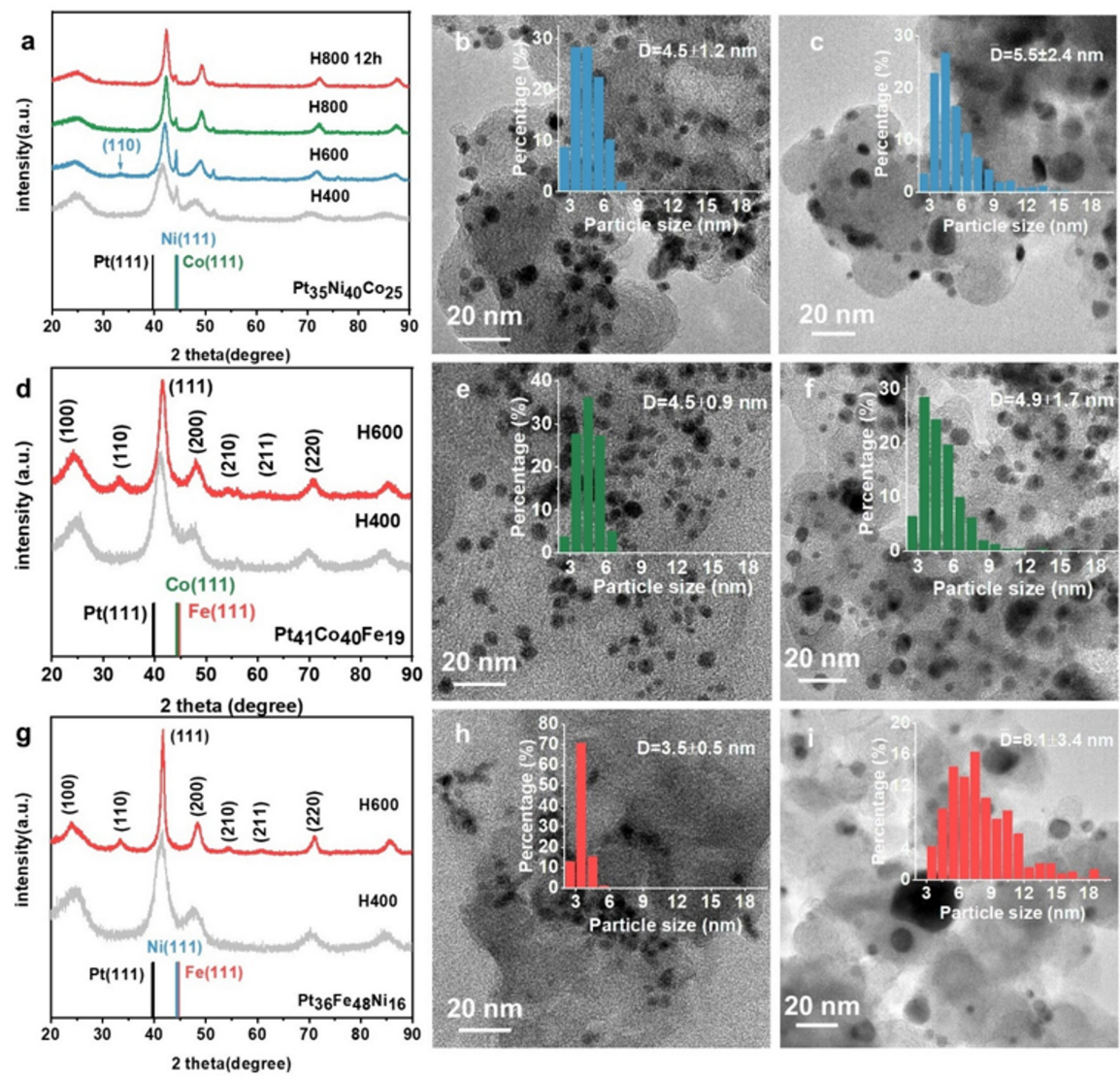

Figure 1. The XRD patterns and TEM images of ternary alloys after annealing. (a,d,g) XRD patterns; $(\mathbf{b}, \mathbf{c}, \mathbf{e}, \mathbf{f}, \mathbf{h}, \mathbf{i})$ TEM images and corresponding particle size distributions of PtNiCo, PtCoFe, and PtFeNi annealed at $400{ }^{\circ} \mathrm{C}$ and $600{ }^{\circ} \mathrm{C}$, respectively.

The different extents of ordering transition of the three alloys indicate a significant influence of the alloying elements during the thermal annealing induced structural ordering. In particular, it appears that Fe could efficiently promote the ordering transformation of $\mathrm{Pt}$ alloys. This can be firstly rationalized by the difference in the diffusion rates of the $\mathrm{Fe}, \mathrm{Co}$, and $\mathrm{Ni}$ atoms as reported by Duhls [24] et al. It was shown that the diffusion coefficients of $\mathrm{Fe}, \mathrm{Co}$, and $\mathrm{Ni}$ in the $\mathrm{Au}$ matrix decreases in the order of $\mathrm{Fe}>\mathrm{Co}>\mathrm{Ni}$. While no reference data was reported for the diffusion rates of $\mathrm{Fe}, \mathrm{Co}$, and $\mathrm{Ni}$ in $\mathrm{Pt}$ matrix, it is reasonable to expect a similar trend in Pt. Thus, the much faster diffusion rate of Fe can speed up the rearrangement of different alloying atoms during the structural ordering. Secondly, from the phase diagrams, the disorder-order transformation temperature of $\mathrm{L} 1_{0}$ PtFe intermetallics ( $850{ }^{\circ} \mathrm{C}$ [25]) was also higher compared to those of $\mathrm{L}_{0} \mathrm{PtCo}$ (around $800{ }^{\circ} \mathrm{C}$ [26]) and $\mathrm{L} 1_{0} \mathrm{PtNi}\left(\sim 600^{\circ} \mathrm{C}\right.$ [27]). A higher disorder-order transition temperature generally indicates a higher stability of the ordered phase at low temperatures, thus the ordered phase of PtFe should be more easily formed when cooling from high temperatures to room temperature [28].

According to the XRD patterns of the three alloys, the diffraction peaks of PtNiCo and PtCoFe do not show obvious sharpening after high-temperature annealing, implying that the NPs did not undergo serious growth; in contrast, the XRD peaks of PtFeNi-H600 appear to be significantly narrower. Since both the PtNiCo and PtCoFe contain Co, we speculate that Co can effectively inhibit the agglomeration of NPs during high-temperature annealing. Figure $1 \mathrm{~b}, \mathrm{e}, \mathrm{h}$ presents the TEM images and the corresponding particle size distribution analysis of the three ternary alloys after annealing at $400{ }^{\circ} \mathrm{C}$, while $1 \mathrm{c}$, f, and i show the three alloys annealed at $600{ }^{\circ} \mathrm{C}$, respectively. The particle sizes of the PtNiCo-H600 and PtCoFe-H600 catalysts, particularly the latter with a higher Co content, increased only slightly compared to their counterparts annealed at $400{ }^{\circ} \mathrm{C}$. In contrast, the Co-free 
PtFeNi NPs grew significantly from $3.5 \pm 0.5 \mathrm{~nm}$ to $8.1 \pm 3.4 \mathrm{~nm}$. The detailed reason for the role of $\mathrm{Co}$ in suppressing particle sintering was still unclear. Nevertheless, a strong interaction of $\mathrm{Ni}$ on the carbon support was previously shown to be responsible for the significant growth of $\mathrm{PtNi}_{3}$ nanoparticles during thermal annealing [29]. Likely, the extent of interaction with the carbon support may be different for $\mathrm{Fe}, \mathrm{Co}$, and $\mathrm{Ni}$, leading to the different extent of particle sintering.

X-ray photoelectron spectroscopy (XPS) was conducted to probe surface composition changes upon annealing at different temperatures, exemplified by the PtCoFe-H400 and the PtCoFe-H600 catalyst (Figure 2). The Pt $4 \mathrm{f}$ spectra of the PtCoFe-H400 catalyst can be fitted by two pairs of peaks corresponding to the $\mathrm{Pt}(0)$ and $\mathrm{Pt}(\mathrm{II})$ species, respectively (Figure $2 \mathrm{a}$ ), showing a majority of metallic $\mathrm{Pt}(0)$ on the surface. The less noble metals $\mathrm{Co}$ and $\mathrm{Fe}$, however, mainly exist in the oxidized state, showing the majority of $\mathrm{Co}^{2+}$ and $\mathrm{Fe}^{3+}$ on the surface (Figure $2 \mathrm{~b}, \mathrm{c}$ ). Importantly, the Pt surface composition substantially increased from 23 at.\% in the the PtCoFe-H400 catalyst to 31 at.\% in the PtCoFe-H600 catalyst (Figure 2d), which is closer to the bulk compositions and thus consistent with a higher extent of alloying in the latter. Moreover, a shift of the $\mathrm{Pt} 4 \mathrm{f}$ peak to lower binding energies and a slight shift of Co-/Fe-2p peaks to higher binding energies are also observed in the PtCoFe-H600 catalyst as guided by the dash lines. This indicates increased electron transfer from $\mathrm{Co} / \mathrm{Fe}$ to $\mathrm{Pt}$ in the ordered PtCoFe-H600 catalyst, leading to a downward shift of d-band center which is believed to be beneficial for ORR electrocatalysis [3].
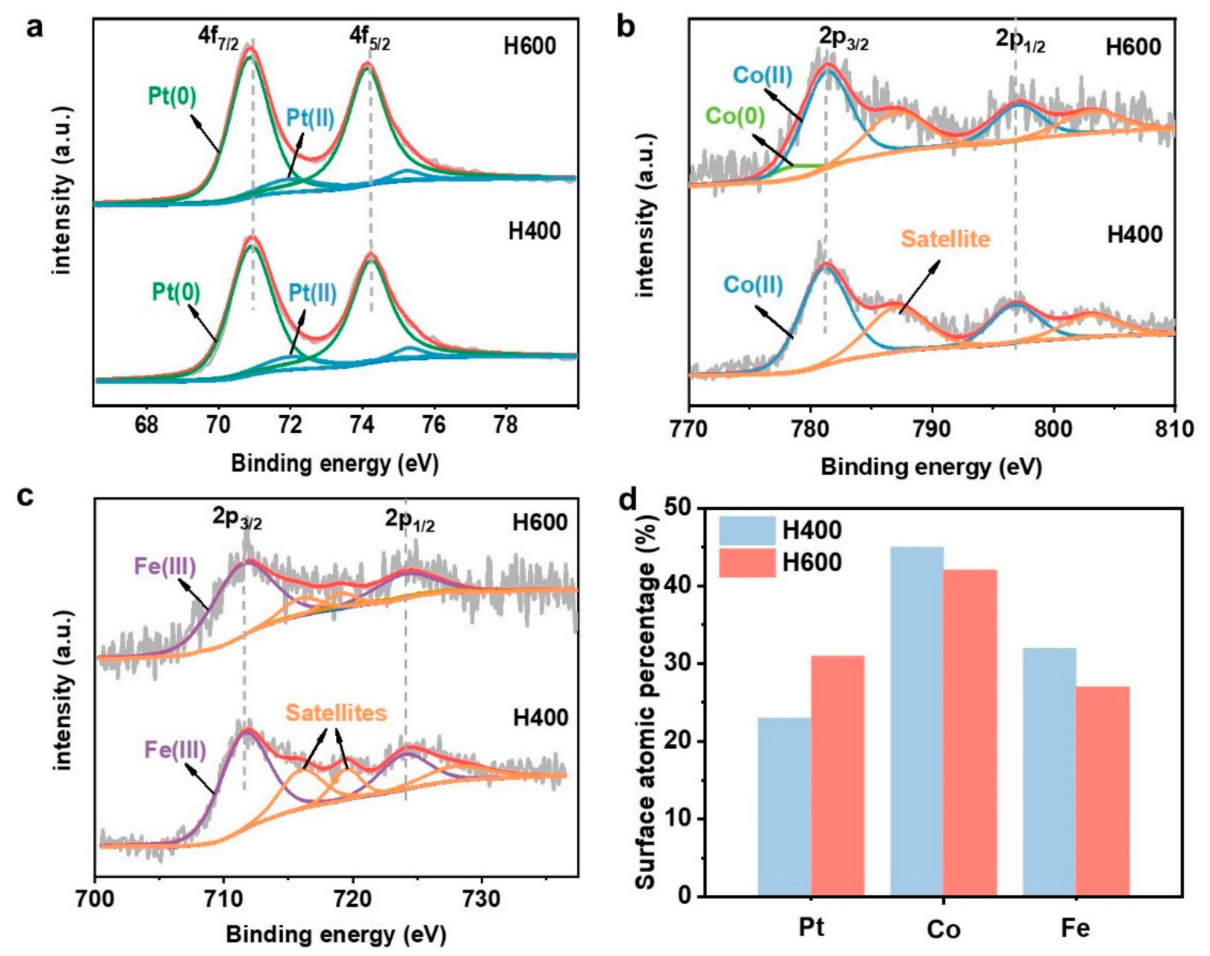

Figure 2. X-ray photoelectron spectroscopy (XPS) spectra of Pt-4f (a), Co-2p (b), Fe-2p (c), and the surface atomic composition (d) of Pt, $\mathrm{Co}$, and Fe in the PtCoFe-H400 and PtCoFe-H600 catalyst.

In order to study the atomic ordering structure of the ordered Pt ternary alloys, the PtCoFe-H600 and PtFeNi-H600 were further characterized by high resolution TEM. Figure 3a presents a high-resolution TEM image of a PtFeCo-H600 nanoparticle oriented along the [01 $\overline{1}$ ] zone axis, showing the partially ordered structure where (100) and (0 $\overline{1} \overline{1})$ superlattice diffraction spots emerged, corresponding to an interplanar spacing of $3.8 \AA$ and $2.7 \AA$, respectively [30]. The EELS elemental mapping of the $\mathrm{PtCoFe}-\mathrm{H} 600$ catalyst (Figure $3 \mathrm{~b}$ ) shows that $\mathrm{Pt}, \mathrm{Fe}$, and $\mathrm{Co}$ are uniformly distributed. Similar to $\mathrm{PtFeCo}-\mathrm{H} 600$, the PtFeNi-H600 is also partially ordered (Figure 3c). Structurally ordered regions and 
disordered regions coexist inside the particles, and the elements are evenly distributed in the NPs (Figure 3d).

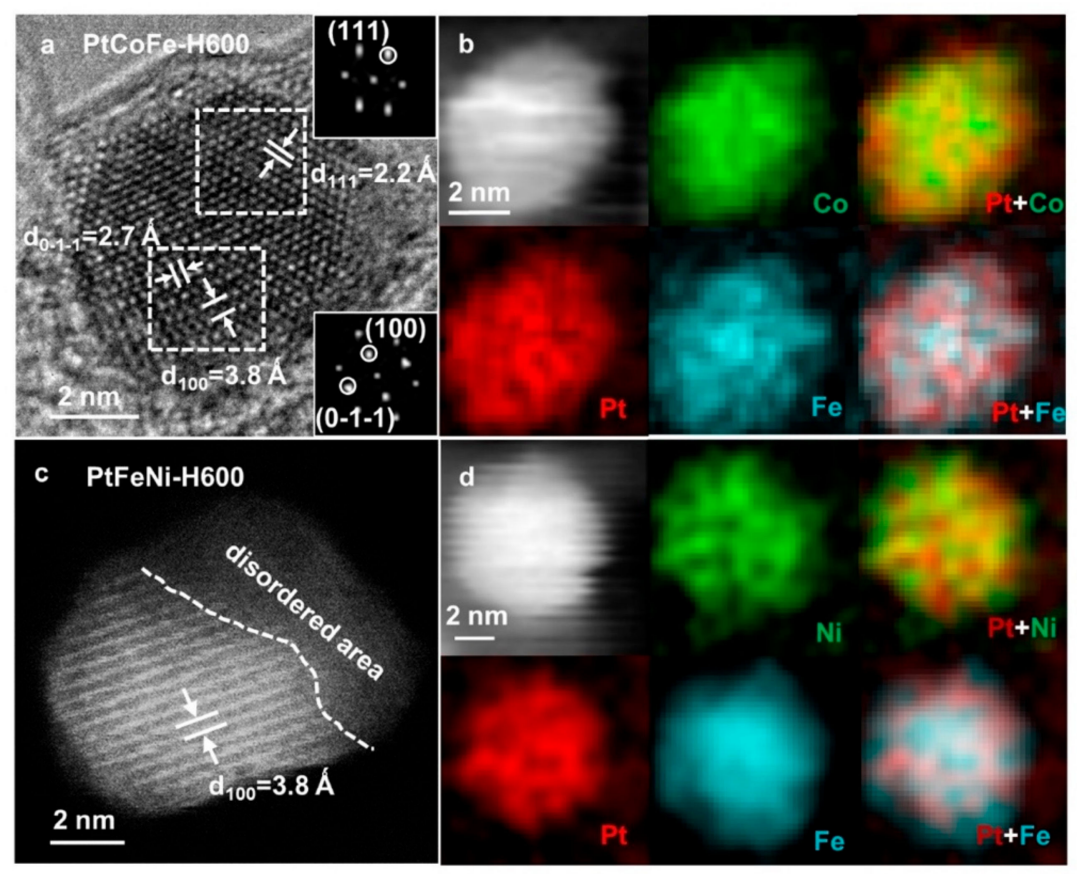

Figure 3. The high-resolution TEM, scanning transmission electron microscopy (STEM), and electron energy loss spectroscopy (EELS) characterizations of PtCoFe-H600 and PtFeNi-H600. (a,b) HRTEM image and EELS mapping of PtCoFe-H600; (c,d) STEM image and EELS mapping of PtFeNi-H600.

Electrochemical tests were performed to evaluate ORR performances of the different Pt ternary alloys. Before the activity measurement, all the catalysts were subjected to electrochemical dealloying by 200 potential cycles between 0.06 and $1.0 \mathrm{~V}$ vs. reversible hydrogen electrode (RHE), which is crucial to achieve the optimum activity (Figure S1). Figure 4a presents the cyclic voltammetry (CV) curves of different catalysts annealed at $600{ }^{\circ} \mathrm{C}\left(\mathrm{CV}\right.$ curves of catalysts annealed at $400{ }^{\circ} \mathrm{C}$ are presented in Figure S2), which show that the PtCoFe-H600 catalyst has the largest electrochemical surface area (ECSA, see quantitative value in Table S3), consistent with its minimum particle sintering effect. Figure $4 \mathrm{~b}-\mathrm{d}$ presents the linear scanning voltammetry (LSV) polarization curves of the dealloyed ternary alloy catalysts on the ORR electrocatalysis, for which the mass activities are compared in Figure 4e. The half-wave potentials were also listed in Table S4 for comparison. It can be seen that the ORR activity of PtNiCo-H600 is only slightly higher than that of PtNiCo-H400 due to a rather low degree of ordering transformation in the absence of Fe. Although PtFeNi-H600 exhibits a higher degree of ordering transition, its ORR mass activity is even lower than that of PtFeNi-H400, which is ascribed to the severe nanoparticle sintering in PtFeNi-H600. No significant activity enhancement was observed in Ni-containing ternary species, indicating Ni addition did not favor the performance improvement. Above all, the PtCoFe-H600 catalyst shows the highest mass activity, increasing from 0.44 (for PtCoFe-H400) to $0.65 \mathrm{~A} / \mathrm{mg}_{\mathrm{Pt}}$, which can be attributed to its relatively high degree of ordering and the presence of Co inhibiting the NP sintering (Figure 4e). The activity of the $\mathrm{PtCoFe}-\mathrm{H} 600$ catalyst is among the highest activities reported in Pt ternary catalysts in the references [18,20-23] (as listed in Table 1). 

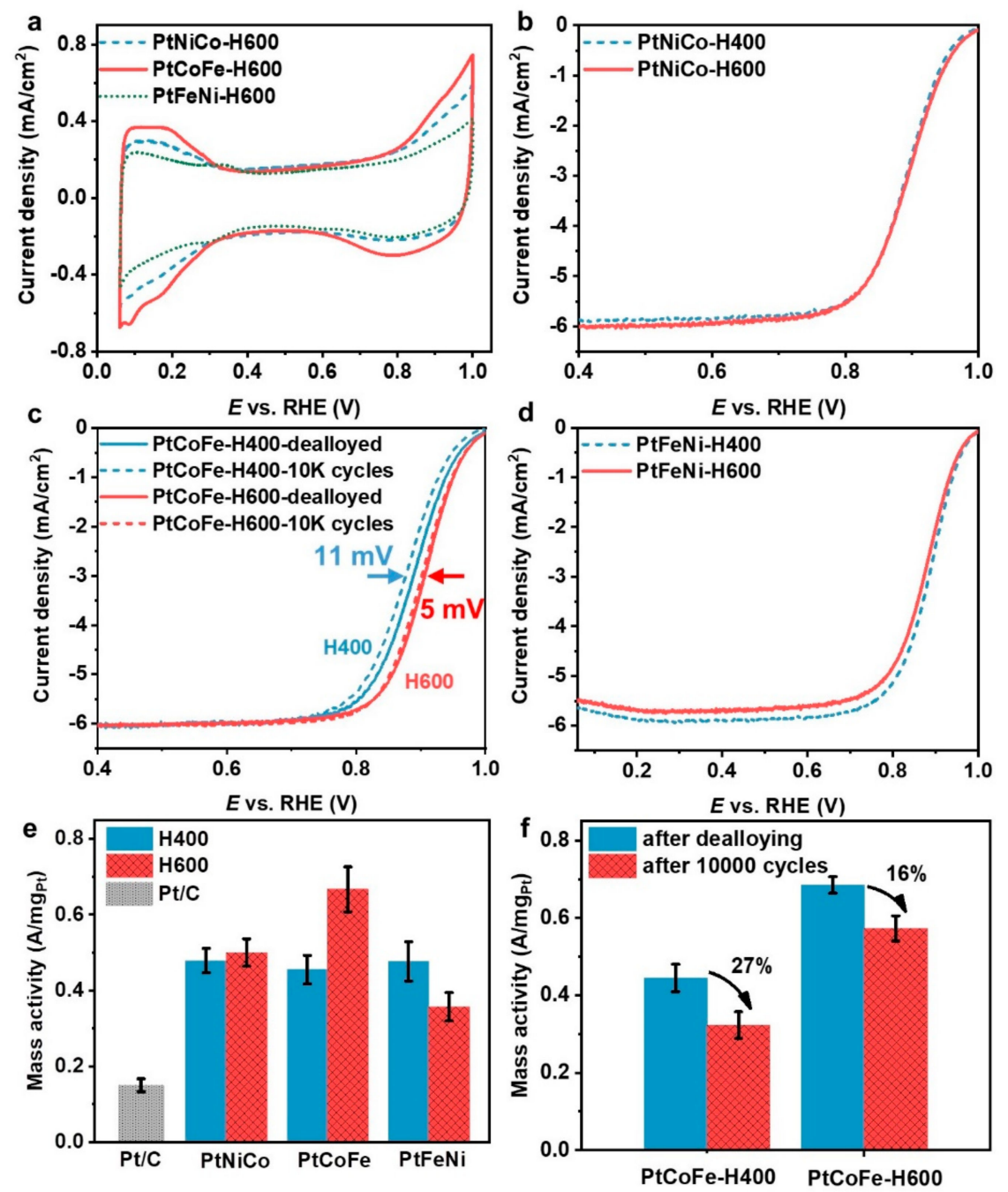

Figure 4. The electrochemical testing results of ternary alloys annealed at 400 and $600{ }^{\circ} \mathrm{C}$. (a) The CV curves of PtMN-H600; (b-d) LSV profiles of PtNiCo, PtCoFe, and PtFeNi, respectively; (e) the column figure of mass activities of ternary alloys and $\mathrm{Pt} / \mathrm{C} ;(\mathbf{f})$ the comparison of the stability of disordered and ordered PtCoFe.

Table 1. Comparison of mass activities of reported Pt ternary intermetallics and the ordered PtCoFe in this work.

\begin{tabular}{ccc}
\hline Catalysts & Mass Activity & Ref. \\
\hline $\mathrm{Pt}_{2} \mathrm{FeCo}$ & $0.51 \mathrm{~A} / \mathrm{mg}_{\mathrm{Pt}}$ & {$[23]$} \\
$\mathrm{Pt}_{6} \mathrm{FeCo}$ & $0.27 \mathrm{~A} / \mathrm{mg}_{\mathrm{Pt}}$ & {$[23]$} \\
$\mathrm{Pt}_{2} \mathrm{CoNi}$ & $63.4 \mathrm{~mA} / \mathrm{mg}_{\mathrm{Pt}}$ & {$[24]$} \\
$\mathrm{Pt}_{2} \mathrm{FeCo}$ & $66.5 \mathrm{~mA} / \mathrm{mg}_{\mathrm{Pt}}$ & {$[24]$} \\
$\mathrm{Pt}_{2} \mathrm{FeNi}$ & $68.4 \mathrm{~mA} / \mathrm{mg}_{\mathrm{Pt}}$ & {$[24]$} \\
$\mathrm{Pt}_{2} \mathrm{FeCu}$ & $0.53 \mathrm{~A} / \mathrm{mg}_{\mathrm{Pt}}$ & {$[20]$} \\
$\mathrm{Pt}_{2} \mathrm{NiCo}(\mathrm{fully}$ ordered $)$ & $2.25 \mathrm{~A} / \mathrm{mg}_{\mathrm{Pt}}$ & {$[21]$} \\
$\mathrm{PtCoFe}$ & $0.65 \mathrm{~A} / \mathrm{mg}_{\mathrm{Pt}}$ & This work \\
\hline
\end{tabular}

We further studied the stability of the disordered and ordered PtCoFe by cycling 10,000 times at a rate of $100 \mathrm{mV} / \mathrm{s}$ in the range of 0.6 to $1.0 \mathrm{~V}$ (Figure $4 \mathrm{c}, \mathrm{f}$ ). The half-wave potential of the disordered PtCoFe-H400 catalyst decreased by 11-12 mV after long-term cycling, and the mass activity reduced by $27 \pm 2 \%$. In contrast, the half-wave potential of the PtCoFe-H600 catalyst shifted only $5-7 \mathrm{mV}$ and the activity dropped by $16 \pm 5 \%$. This demonstrates the ordered PtCoFe-H600 catalyst has both higher 
catalytic activity and higher durability compared to the disordered PtCoFe-H400 catalyst as well as the other Pt ternary catalysts. EDS analysis (Table S5) demonstrates that the composition of PtCoFe-H400 changed to $\mathrm{Pt}_{71} \mathrm{Co}_{19} \mathrm{Fe}_{10}$ after dealloying, while the composition of $\mathrm{PtCoFe}-\mathrm{H} 600$ became $\mathrm{Pt}_{58} \mathrm{Co}_{24} \mathrm{Fe}_{18}$ after dealloying and $\mathrm{Pt}_{64} \mathrm{Co}_{18} \mathrm{Fe}_{18}$ after 10,000 cycles, evidencing that the nonprecious metals in the ordered alloy are more difficult to be leached.

Compositional fine structures of the disordered PtCoFe-H400 and ordered PtCoFe-H600 catalysts after ORR test were further investigated by STEM-EELS to gain further insights into their different activities and stabilities. Some of the particles in the PtCoFe-H400 catalyst were etched into a porous structure (Figure 5a,b). EELS characterizations confirm that some of the internal Fe and Co were etched (Figure $5 \mathrm{c}$ ) to form a hollow structure, in accordance with the sharp decrease in the total content of $\mathrm{Fe} / \mathrm{Co}$ derived from EDS analysis. For the nonporous solid particles (Figure 5d), EELS mapping indicates a thick Pt shell up to $1 \mathrm{~nm}$. Both of the porous structure and the thick Pt shell layer in the NPs cause a low compressive stress on the surface $\mathrm{Pt}$ [31], explaining why the activity of PtCoFe-H400 is relatively poorer. In contrast, the ordered PtCoFe-H600 catalyst has almost no pores (Figure 5e), but a solid core-shell structure with a thin outer layer of Pt (Figure 5f,g). This reflects the ordered structure of PtCoFe-H600 can effectively protect non-noble metals from being etched and avoid the formation of porous structures. The resulting thinner Pt shell and the higher internal Fe/Co content make the ordered PtCoFe exhibit higher ORR performance.
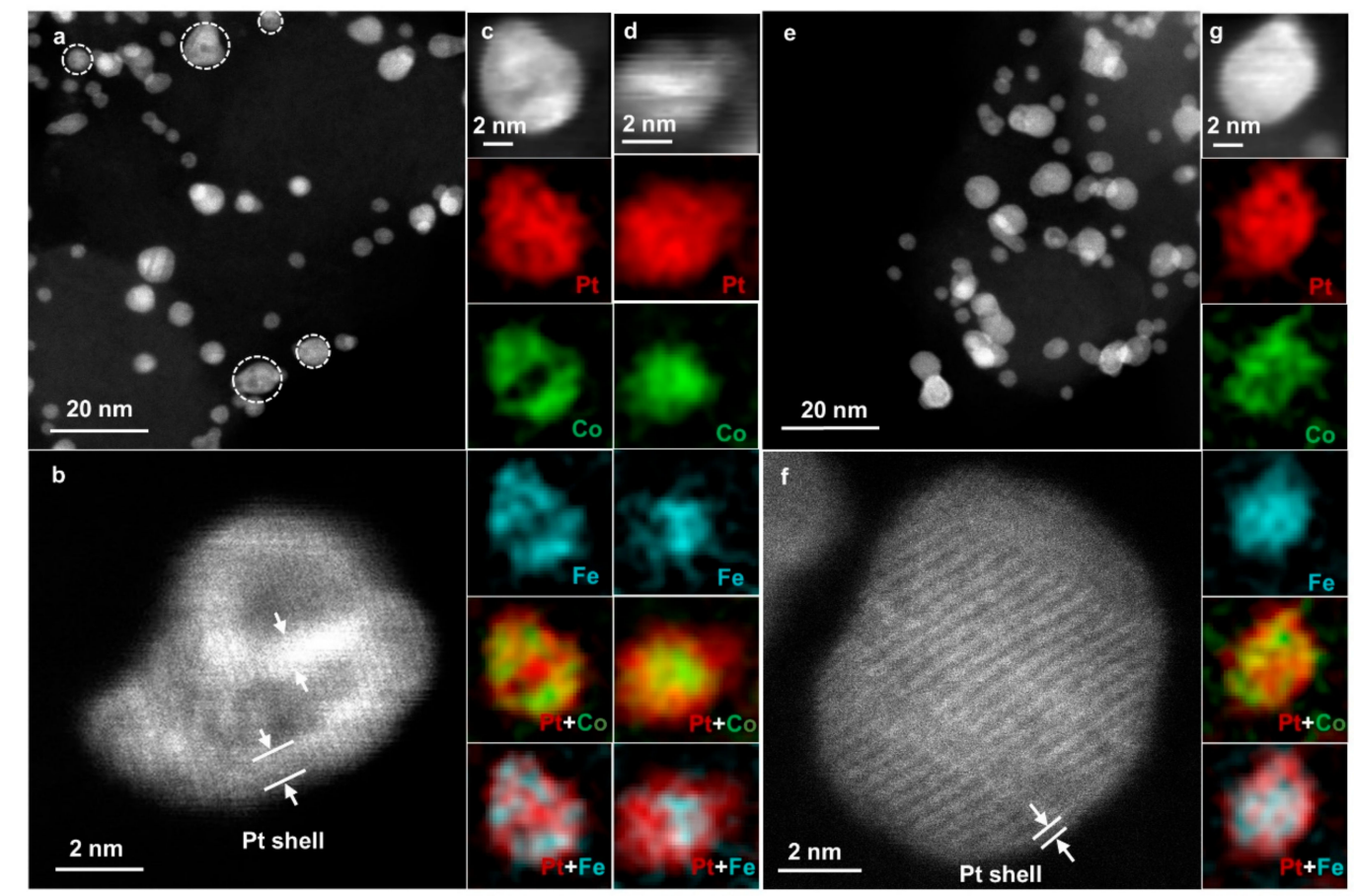

Figure 5. The STEM-EELS characterizations of disordered and ordered PtCoFe after dealloying. (a,b,e,f) STEM images of dealloyed PtCoFe-H400 and PtCoFe-H600 respectively; (c,d,g) EELS mapping of dealloyed PtCoFe-H400 and PtCoFe-H600, respectively.

To further evidence the role of Fe in promoting the structural ordering, we also compared the PtCoFe-H600 catalyst $\left(\mathrm{Pt}_{41} \mathrm{Co}_{40} \mathrm{Fe}_{19}\right)$ with a homemade $\mathrm{Pt}_{40} \mathrm{Co}_{60}$ alloy catalyst at a similar Pt content (TEM and EDS results are shown in Figure S3). The $\mathrm{Pt}_{40} \mathrm{Co}_{60}$ is still disordered after annealing at $600{ }^{\circ} \mathrm{C}$ (Figure 6a), while $\mathrm{Pt}_{41} \mathrm{Co}_{40} \mathrm{Fe}_{19}$ can be transformed into ordered phase after annealing at the same temperature for the same time. This suggests that the introduction of Fe with faster atomic diffusion rate can do promote the formation of structurally ordered structure [24]. The ORR tests of $\mathrm{Pt}_{40} \mathrm{Co}_{60}$ annealed at $400{ }^{\circ} \mathrm{C}$ and $600{ }^{\circ} \mathrm{C}\left(\mathrm{Pt}_{40} \mathrm{Co}_{60}-\mathrm{H} 400\right.$ and $\mathrm{Pt}_{40} \mathrm{Co}_{60}-\mathrm{H} 600$, respectively) (Figure $\mathrm{S} 4$ and Figure $6 \mathrm{~b}$ ) indicate the mass activity of $\mathrm{Pt}_{40} \mathrm{Co}_{60}-\mathrm{H} 600$ did not increase, but instead decreased slightly 
(from 0.42 to $\left.0.36 \mathrm{~A} / \mathrm{mg}_{\mathrm{Pt}}\right)$. The ORR activity of ordered $\mathrm{Pt}_{41} \mathrm{Co}_{40} \mathrm{Fe}_{19}\left(0.65 \mathrm{~A} / \mathrm{mg}_{\mathrm{Pt}}\right)$ is substantially higher than that of $\mathrm{Pt}_{40} \mathrm{Co}_{60}-\mathrm{H} 600$ and four times of $\mathrm{Pt} / \mathrm{C}$ catalyst $\left(0.15 \mathrm{~A} / \mathrm{mg}_{\mathrm{Pt}}\right)$, which evidences the great advantage of ordered ternary alloys as ORR catalysts.
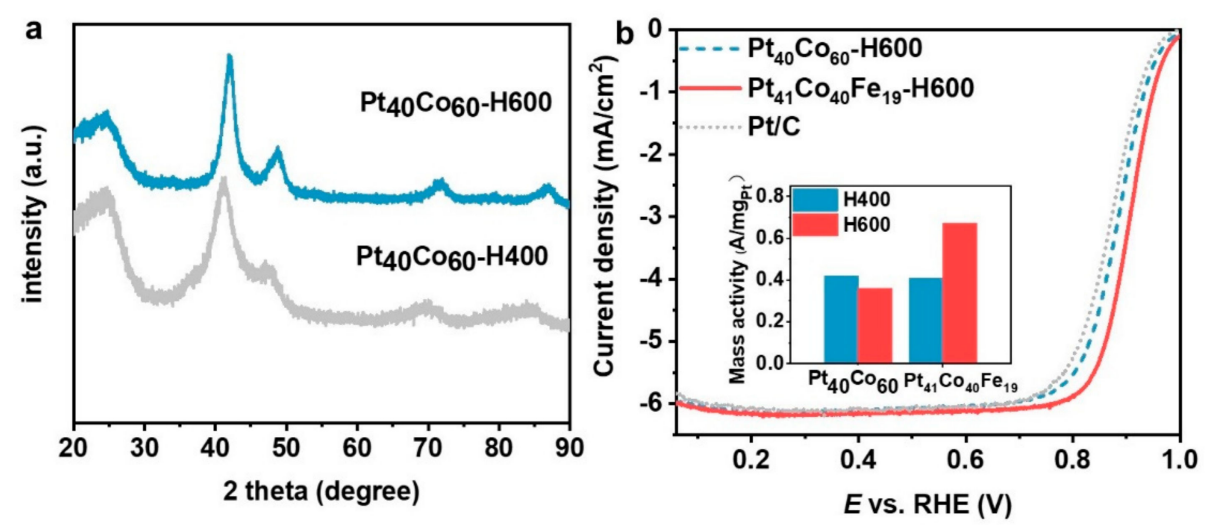

Figure 6. The comparison of $\mathrm{Pt}_{41} \mathrm{Co}_{40} \mathrm{Fe}_{19}$ and $\mathrm{Pt}_{40} \mathrm{Co}_{60}$. (a) The XRD patterns of $\mathrm{Pt}_{40} \mathrm{Co}_{60}-\mathrm{H} 400$ and $\mathrm{Pt}_{40} \mathrm{Co}_{60}-\mathrm{H} 600 ;(\mathbf{b})$ the activities of $\mathrm{Pt} / \mathrm{C}, \mathrm{Pt}_{40} \mathrm{Co}_{60}$ and $\mathrm{Pt}_{41} \mathrm{Co}_{40} \mathrm{Fe}_{19}$.

\section{Experiments}

Chemicals: Platinum acetylacetonate $\left(\mathrm{Pt}(\mathrm{acac})_{2}\right.$, platinum $\left.48 \%\right)$, nickel acetylacetonate $\left(\mathrm{Ni}(\mathrm{acac})_{2}\right)$, cobalt acetylacetonate $\left(\mathrm{Co}(\mathrm{acac})_{2}\right)$, iron acetylacetonate $\left(\mathrm{Fe}(\mathrm{acac})_{3}\right)$, nickel acetate tetrahydrate $\left(\mathrm{Ni}(\mathrm{ac})_{2} \cdot 4 \mathrm{H}_{2} \mathrm{O}, 99.999 \%\right)$, and dichlorobenzene $(\mathrm{DCB}, 99 \%)$ were purchased from Alfa Aesar (Heysham, UK). Benzyl ether (BE, 98\%), oleylamine (OAm, 70\%), oleic acid (OAc, 90\%), tetradecanediol (TDD, 90\%), and hexadecanediol (HDD, 90\%) were bought from Sigma Alrich (Saint Louis, MS, USA). Cobalt acetate tetrahydrate $\left(\mathrm{Co}(\mathrm{ac})_{2} \cdot 4 \mathrm{H}_{2} \mathrm{O}\right)$, trioctylamine (TOAm, $\left.97 \%\right)$, and n-hexane (analytical grade) were bought from Sinopharm (Beijing, China), Acros Organics (Belgium) and Hushi (Shanghai, China), respectively. All reagents were not further purified.

Synthesis of ternary Pt alloys: The synthesis of ternary Pt-alloy nanoparticles (NPs) was carried out by organic liquid phase reduction methods [32-34]. The synthesis of $\mathrm{Pt}-\mathrm{Ni}-\mathrm{Co} \mathrm{NPs}$ was carried out according to the following procedure; $0.2 \mathrm{mmol} \mathrm{Ni}(\mathrm{ac})_{2} \cdot 4 \mathrm{H}_{2} \mathrm{O}, 0.3 \mathrm{mmol} \mathrm{Co}(\mathrm{ac})_{2} \cdot 4 \mathrm{H}_{2} \mathrm{O}, 50 \mathrm{mg}$ TDD, $0.2 \mathrm{~mL} \mathrm{OAm}$, and $0.2 \mathrm{~mL}$ OAc were dissolved in $15 \mathrm{~mL}$ BE contained in a $50 \mathrm{~mL}$ three-necked flask. Then, the mixture was heated at $110^{\circ} \mathrm{C}$ for $30 \mathrm{~min}$ to remove residual water in the reaction system; $0.1 \mathrm{mmol}$ of $\mathrm{Pt}(\mathrm{acac})_{2}$ dissolved in $0.75 \mathrm{~mL} \mathrm{DCB}$ was injected immediately as soon as the temperature was elevated to $200{ }^{\circ} \mathrm{C}$ and the reaction was hold for $1 \mathrm{~h}, 20 \mathrm{~mL}$ ethanol was added, and the mixture was centrifuged at $8000 \mathrm{r} / \mathrm{min}$ for $10 \mathrm{~min}$.

The Pt-Co-Fe ternary alloy NPs were prepared by the following method: $0.4 \mathrm{mmol} \mathrm{Fe}(\mathrm{acac})_{3}$ and $0.2 \mathrm{mmol} \mathrm{Co(ac})_{2} \cdot 4 \mathrm{H}_{2} \mathrm{O}, 50 \mathrm{mg}$ TDD, $0.2 \mathrm{~mL}$ OAm, $0.2 \mathrm{~mL}$ OAc were dissolved in $15 \mathrm{~mL} \mathrm{BE}$; after the water removal step, the temperature was raised to $200{ }^{\circ} \mathrm{C}$, and kept at this temperature for $2 \mathrm{~h}$; $0.1 \mathrm{mmol}$ of $\mathrm{Pt}(\mathrm{acac})_{2}$ dissolved in $0.75 \mathrm{~mL} \mathrm{DCB}$ was injected, and the temperature was raised to $240^{\circ} \mathrm{C}$ for $1 \mathrm{~h}$; the obtained colloid mixed with $20 \mathrm{~mL}$ ethanol was centrifuged at $8000 \mathrm{r} / \mathrm{min}$ for $10 \mathrm{~min}$.

Synthesis of Pt-Fe-Ni ternary alloy NPs was carried out as follows: $0.175 \mathrm{mmol} \mathrm{Pt(acac})_{2}$, $0.25 \mathrm{mmol} \mathrm{Fe}(\mathrm{acac})_{3}, 0.075 \mathrm{mmol} \mathrm{Ni}(\mathrm{acac})_{2}, 1 \mathrm{mmol} \mathrm{HDD}$, and $0.25 \mathrm{~mL}$ OAc were dissolved in $20 \mathrm{~mL}$ TOAm; after the water removal step, the temperature was raised to $330^{\circ} \mathrm{C}$ for $1 \mathrm{~h}$; the resulted colloid was added with $20 \mathrm{~mL}$ ethanol and centrifuged at $8000 \mathrm{r} / \mathrm{min}$ for $10 \mathrm{~min}$. The above reactions were all carried out under an argon atmosphere. The centrifuged nanoparticles were separately dispersed in hexane and a calculated amount of carbon black (Vulcan XC72, designed Pt mass percentage of $15 \%)$ was added. The mixture was ultrasonicated with a cell pulverizer for $15 \mathrm{~min}$, followed by centrifugation at $8000 \mathrm{r} / \mathrm{min}$ for $5 \mathrm{~min}$, and finally the carbon-supported NPs were dried in a vacuum oven at $60^{\circ} \mathrm{C}$ for $12 \mathrm{~h}$. 
Thermal annealing of nanoparticles: The carbon-supported ternary alloy NPs were first heated in air at $180^{\circ} \mathrm{C}$ for $1 \mathrm{~h}$ to remove the surfactants on the nanoparticle surface, and then argon was introduced for $30 \mathrm{~min}$ to remove the air, followed by purging $\mathrm{Ar} / 4 \% \mathrm{H}_{2}$ for another $30 \mathrm{~min}$ to create a reductive atmosphere. Then the temperature was elevated to $400{ }^{\circ} \mathrm{C}$ and kept for $4 \mathrm{~h}$ to realize alloying and disordered alloys were prepared. The disordered ternary alloy catalysts were further annealed at $600{ }^{\circ} \mathrm{C}$ for $4 \mathrm{~h}$ in an atmosphere of $\mathrm{Ar} / 4 \% \mathrm{H}_{2}$ and then naturally cooled down to realize ordering transformation. In addition, the Pt-Ni-Co ternary alloy was annealed at $800{ }^{\circ} \mathrm{C}$ for $4 \mathrm{~h}$ and $12 \mathrm{~h}$, respectively.

Electrochemical tests: Electrochemical tests were performed on a BioLogic electrochemical workstation (Seyssinet-Pariset, France). The working electrode was a PINE rotating disk electrode loading a catalyst film, the reference electrode was a $\mathrm{Hg} / \mathrm{Hg}_{2} \mathrm{SO}_{4}$ electrode, and the counter electrode was a Pt mesh electrode. To prepare the working electrode, a catalyst slurry was prepared at catalyst concentration of $1.6 \mathrm{mg} / \mathrm{mL}$, with the solvent consisting of a mixture of isopropanol, ultrapure water, and 5\% Nafion (volume ratio: 1:4:0.02). Ten microliters of the uniformly ultrosonicated slurry was dropped on the glassy carbon region of the polished disk electrode, and dried to obtain a uniform and matte catalyst film. The cyclic voltammetry (CV) test was carried out in $\mathrm{N}_{2}$-saturated $0.1 \mathrm{M} \mathrm{HClO}_{4}$ with a test range of 0.06 to $1.0 \mathrm{~V}$ (vs. reversible hydrogen electrode, RHE, unless otherwise specified) at $100 \mathrm{mV} / \mathrm{s}$. Electrochemical dealloying was conducted by potential cycling between 0.06 and $1.0 \mathrm{~V}$ for 200 cycles at a scanning rate of $500 \mathrm{mV} / \mathrm{s}$. Linear Scanning Voltammetry (LSV) was performed under $\mathrm{O}_{2}$-saturated $0.1 \mathrm{M} \mathrm{HClO}_{4}$ within a range of 0.06 to $1.0 \mathrm{~V}$ at a scanning speed of $5 \mathrm{mV} / \mathrm{s}$. The stability test was carried out by scanning CV for 10,000 cycles at a rate of $100 \mathrm{mV} / \mathrm{s}$ in the range of 0.6 to $1.0 \mathrm{~V}$.

Materials Characterization: Transmission electron microscopy (TEM) characterizations were performed on FEI TECNAI G ${ }^{2}$ T12 (acceleration voltage of $120 \mathrm{kV}$, Netherlands). Scanning transmission electron microscopy (STEM) and electron energy loss spectroscopy (EELS) characterizations were performed on a FEI TECNAI G ${ }^{2}$ F30 electron microscope (acceleration voltage $300 \mathrm{kV}$, Netherlands) equipped with a Gatan GIF 965 EELS spectrometer (Pleasanton, CA, USA). X-ray diffraction (XRD) was performed on a Bruker D8 Advance diffractometer with a copper target (wavelength $1.5406 \AA$, Karlsruhe, Germany), a scanning range of 20 to $90^{\circ}$, and a stepping rate of $5^{\circ} / \mathrm{min}$. Inductively Coupled Plasma mass Spectrometry (ICP-MS, SPECTRO, Kleve, Germany) was used to test the compositions of prepared alloys. The standard sample digestion process of ICP tests was carried out by adding $10 \mathrm{mg}$ of catalyst to $12 \mathrm{~mL}$ of aqua regia, heating at $120^{\circ} \mathrm{C}$ for $30 \mathrm{~min}$, and filtering. Finally, the obtained solution was diluted with water to $250 \mathrm{~mL}$.

\section{Conclusions}

In summary, the high-temperature annealing of the three representative $\mathrm{Pt}$ ternary alloy catalysts (PtCoFe, PtNiCo, and PtFeNi) with a similar Pt content of $\sim 40 \%$ at $600{ }^{\circ} \mathrm{C}$ resulted in distinctly different behaviors in particle sintering and structural ordering, and thus electrocatalytic performance towards $\mathrm{ORR}$, indicating a pronounced effect of the alloying element. After annealing at $600^{\circ} \mathrm{C}$, the Fe-containing $\mathrm{PtFeNi}$ and PtCoFe alloys showed a higher extent of ordering transformation compared to the Fe-free PtNiCo ternary alloy (low ordering degree) and $\mathrm{Pt}_{40} \mathrm{Co}_{60}$ binary alloy (no ordering phase at all), indicating that Fe can effectively promote the ordering transformation, likely due to a higher atomic diffusion rate in the alloy. Meanwhile, both Co-containing PtNiCo and PtCoFe ternary alloys underwent much milder particle agglomeration compared to the Co-free $\mathrm{PtFeNi}$, indicating that $\mathrm{Co}$ can inhibit the agglomeration of NPs during high-temperature annealing, which can be ascribed to a minimum interaction with the carbon support. Therefore, the PtCoFe ternary catalyst containing both Co and Fe elements can not only achieve a higher degree of ordering, but also suppresses severe particle agglomeration after thermal annealing, leading to a thin Pt shell and a core-shell structure with a high nonprecious metal content under acidic ORR conditions, and thereby exhibiting excellent ORR electrocatalytic activity and stability. 
Supplementary Materials: The following are available online at http://www.mdpi.com/2073-4344/9/7/569/s1, Figure S1: ORR LSV curves before and after electrochemical dealloying by 200 potential cycles between 0.06 and $1.0 \mathrm{~V} / \mathrm{RHE}$ at $500 \mathrm{mV} / \mathrm{s}$, Figure S2: The CV curves of dealloyed ternary alloys annealed at $400^{\circ} \mathrm{C}$, Figure S3: The TEM images and EDS result. (a)The morphology and EDS results of as-prepared $\mathrm{Pt}_{40} \mathrm{Co}_{60}$; (b) the TEM image of $\mathrm{Pt}_{40} \mathrm{Co}_{60}-\mathrm{H} 600$, Figure S4: The electrochemical testing results of $\mathrm{Pt}_{40} \mathrm{Co}_{60}$ annealed at 400 and $600{ }^{\circ} \mathrm{C}$. (a) the CV curves of $\mathrm{Pt}_{40} \mathrm{Co}_{60}-\mathrm{H} 400$ and $\mathrm{Pt}_{40} \mathrm{Co}_{60}-\mathrm{H} 600$; (b) the LSV curves of $\mathrm{Pt}_{40} \mathrm{Co}_{60}-\mathrm{H} 400$ and $\mathrm{Pt}_{40} \mathrm{Co}_{60}-\mathrm{H}_{600}$, Table S1: The EDS and ICP compositions of ternary alloys and their mass percentages of Pt, Table S2: Lattice parameters $(\AA)$ derived from XRD for different Pt ternary catalysts. The lattice parameter for pure Pt is $3.926 \AA$, Table S3: The electrochemical surface areas (ECSAs) of ternary alloys (cm2/mgPt), Table S4: Comparison of the half-wave potentials $\left(\mathrm{E}_{1 / 2}\right)$, mass activities and kinetic currents, Table S5: The EDS compositions of PtCoFe- $\mathrm{H} 400$ and $\mathrm{PtCoFe}-\mathrm{H} 600$ at three different stages.

Author Contributions: Conceptualization, Z.W. and L.G.; Methodology, Z.W. and X.Y.; Software, Y.K. and D.X.; Formal Analysis, Z.W., X.Y., D.X., and Y.K.; Writing-Original Draft Preparation, Z.W.; Writing-Review \& Editing, Z.W. and L.G.; Supervision, L.G.; Project Administration, L.G.

Funding: This research was funded by Natural Science Foundation of China (NSFC) (under grant number 21573123 and 51622103), the Local Innovative and Research Teams Project of Guangdong Pearl River Talents Program (Grant No. 2017BT01N111), Guangdong Natural Science Foundation for Distinguished Young Scholars.

Conflicts of Interest: The authors declare no conflict of interest.

\section{References}

1. Nørskov, J.R.J.K.; Logadottir, A.; Lindqvist, L. Origin of the overpotential for oxygen reduction at a fuel-cell cathode. J. Phys. Chem. B 2004, 108, 17886-17892. [CrossRef]

2. Toda, H.I.T.; Uchida, H.; Watanabe, M. Enhancement of the electroreduction of oxygen on Pt alloys with Fe, $\mathrm{Ni}$, and Co. J. Electrochem. Soc. 1999, 146, 3750-3756. [CrossRef]

3. Stamenkovic, V.; Mun, B.S.; Mayrhofer, K.J.J.; Ross, P.N.; Markovic, N.M.; Rossmeisl, J.; Greeley, J.; Nørskov, J.K. Changing the activity of electrocatalysts for oxygen reduction by tuning the surface electronic structure. Angew. Chem. 2006, 118, 2963-2967. [CrossRef]

4. Strasser, P.; Koh, S.; Anniyev, T.; Greeley, J.; More, K.; Yu, C.; Liu, Z.; Kaya, S.; Nordlund, D.; Ogasawara, H.; et al. Lattice-strain control of the activity in dealloyed core-shell fuel cell catalysts. Nat. Chem. 2010, 2, 454-460. [CrossRef] [PubMed]

5. $\quad$ Meng, C.; Ling, T.; Ma, T.Y.; Wang, H.; Hu, Z.; Zhou, Y.; Mao, J.; Du, X.W.; Jaroniec, M.; Qiao, S.Z. Atomically and electronically coupled $\mathrm{Pt}$ and $\mathrm{CoO}$ hybrid nanocatalysts for enhanced electrocatalytic performance. Adv. Mater. 2017, 29, 1604607. [CrossRef] [PubMed]

6. Xin, H.L.; Mundy, J.A.; Liu, Z.; Cabezas, R.; Hovden, R.; Kourkoutis, L.F.; Zhang, J.; Subramanian, N.P.; Makharia, R.; Wagner, F.T.; et al. Atomic-resolution spectroscopic imaging of ensembles of nanocatalyst particles across the life of a fuel cell. Nano Lett. 2012, 12, 490-497. [CrossRef] [PubMed]

7. Mayrhofer, K.H.K.J.J.; Juhart, V.; Arenz, M. Degradation of carbon-supported Pt bimetallic nanoparticles by surface segregation. J. Am. Chem. Soc. 2009, 131, 16348-16349. [CrossRef] [PubMed]

8. Kim, J.; Lee, Y.; Sun, S. Structurally ordered FePt nanoparticles and their enhanced catalysis for oxygen reduction reaction. J. Am. Chem. Soc. 2010, 132, 4996-4997. [CrossRef]

9. Li, S.S.J.; Liu, X.; Pan, Y.; Spendelow, J.S.; Chi, M.; Jia, Y.; Zhang, P.; Cullen, D.A.; Xi, Z.; Lin, H.; et al. hard-magnet L10-CoPt nanoparticles advance fuel cell catalysis. Joule 2019, 3, 124-135. [CrossRef]

10. Wang, D.; Xin, H.L.; Hovden, R.; Wang, H.; Yu, Y.; Muller, D.A.; DiSalvo, F.J.; Abruna, H.D. Structurally ordered intermetallic platinum-cobalt core-shell nanoparticles with enhanced activity and stability as oxygen reduction electrocatalysts. Nat. Mater. 2012, 12, 81-87. [CrossRef]

11. Li, J.; Xi, Z.; Pan, Y.T.; Spendelow, J.S.; Duchesne, P.N.; Su, D.; Li, Q.; Yu, C.; Yin, Z.; Shen, B.; et al. Fe stabilization by intermetallic $\mathrm{L} 1_{0}$-FePt and $\mathrm{Pt}$ catalysis enhancement in $\mathrm{L} 1_{0}$-FePt/Pt nanoparticles for efficient oxygen reduction reaction in fuel cells. J. Am. Chem. Soc. 2018, 140, 2926-2932. [CrossRef] [PubMed]

12. Xiao, W.; Lei, W.; Gong, M.; Xin, H.L.; Wang, D. Recent advances of structurally ordered intermetallic nanoparticles for electrocatalysis. ACS Catal. 2018, 8, 3237-3256. [CrossRef]

13. Chen, H.; Wang, D.; Yu, Y.; Newton, K.A.; Muller, D.A.; Abruna, H.; DiSalvo, F.J. A surfactant-free strategy for synthesizing and processing intermetallic platinum-based nanoparticle catalysts. J. Am. Chem. Soc. 2012, 134, 18453-18459. [CrossRef] [PubMed] 
14. Li, Q.; Wu, L.; Wu, G.; Su, D.; Lv, H.; Zhang, S.; Zhu, W.; Casimir, A.; Zhu, H.; Mendoza-Garcia, A.; et al. New approach to fully ordered fct-FePt nanoparticles for much enhanced electrocatalysis in acid. Nano Lett. 2015, 15, 2468-2473. [CrossRef] [PubMed]

15. Chung, D.Y.; Jun, S.W.; Yoon, G.; Kwon, S.G.; Shin, D.Y.; Seo, P.; Yoo, J.M.; Shin, H.; Chung, Y.H.; Kim, H.; et al. Highly durable and active ptfe nanocatalyst for electrochemical oxygen reduction reaction. J. Am. Chem. Soc. 2015, 137, 15478-15485. [CrossRef]

16. Wang, C.; Li, D.; Chi, M.; Pearson, J.; Rankin, R.B.; Greeley, J.; Duan, Z.; Wang, G.; van der Vliet, D.; More, K.L.; et al. Rational development of ternary alloy electrocatalysts. J. Phys. Chem. Lett. 2012, 3, 1668-1673. [CrossRef]

17. Zhang, S.; Zhang, X.; Jiang, G.; Zhu, H.; Guo, S.; Su, D.; Lu, G.; Sun, S. Tuning nanoparticle structure and surface strain for catalysis optimization. J. Am. Chem. Soc. 2014, 136, 7734-7739. [CrossRef]

18. Chen, L.; Bock, C.; Mercier, P.H.J.; MacDougall, B.R. Ordered alloy formation for $\mathrm{Pt}_{3} \mathrm{Fe} / \mathrm{C}, \mathrm{PtFe} / \mathrm{C}$ and $\mathrm{Pt}_{5.75} \mathrm{Fe}_{5.75} \mathrm{Cu}_{\mathrm{y}} / \mathrm{CO}_{2}$-reduction electro-catalysts. Electrochim. Acta 2012, 77, 212-224. [CrossRef]

19. Zhu, Y.Y.J.; Chen, L.; Xiao, W.; Liu, H.; Abruna, H.D.; Wang, D. Copper-induced formation of structurally ordered $\mathrm{Pt}-\mathrm{Fe}-\mathrm{Cu}$ ternary intermetallic electrocatalysts with tunable phase structure and improved stability. Chem. Mater. 2018, 30, 5987-5995. [CrossRef]

20. Wang, T.; Liang, J.; Zhao, Z.; Li, S.; Lu, G.; Xia, Z.; Wang, C.; Jiahuan, L.; Jiantao, H.; Cheng, M.; et al. Sub-6 nm fully ordered $\mathrm{L1}_{0-} \mathrm{Pt}-\mathrm{Ni}$-Co nanoparticles enhance oxygen reduction via Co doping induced ferromagnetism enhancement and optimized surface strain. Adv. Energy Mat. 2019, 9, 1803771. [CrossRef]

21. Zhu, H.; Cai, Y.; Wang, F.; Gao, P.; Cao, J. Scalable preparation of the chemically ordered Pt-Fe-Au nanocatalysts with high catalytic reactivity and stability for oxygen reduction reactions. ACS Appl. Mater. Interfaces 2018, 10, 22156-22166. [CrossRef] [PubMed]

22. Tamaki, T.; Minagawa, A.; Arumugam, B.; Kakade, B.A.; Yamaguchi, T. Highly active and durable chemically ordered $\mathrm{Pt}-\mathrm{Fe}-\mathrm{Co}$ intermetallics as cathode catalysts of membrane-electrode assemblies in polymer electrolyte fuel cells. J. Power Sources 2014, 271, 346-353. [CrossRef]

23. Nguyen, M.T.; Wakabayashi, R.H.; Yang, M.; Abruña, H.D.; DiSalvo, F.J. Synthesis of carbon supported ordered tetragonal pseudo-ternary $\mathrm{Pt}_{2} \mathrm{M}^{\prime} \mathrm{M}^{\prime \prime}(\mathrm{M}=\mathrm{Fe}, \mathrm{Co}, \mathrm{Ni})$ nanoparticles and their activity for oxygen reduction reaction. J. Power Sources 2015, 280, 459-466. [CrossRef]

24. Duhl, D.; Hirano, K.I.; Cohen, M. Diffusion of iron, cobalt and nickel in gold. Acta Met. 1963, 11, 1-6. [CrossRef]

25. Fredriksson, P.; Sundman, B. A Thermaldynamic assessment of the Fe-Pt system. Calphad 2002, 25, 535-548. [CrossRef]

26. Kim, D.; Saal, J.E.; Zhou, L.; Shang, S.; Du, Y.; Liu, Z.-K. Thermodynamic modeling of fcc order/disorder transformations in the Co-Pt system. Calphad 2011, 35, 323-330. [CrossRef]

27. Lu, X.-G.; Sundman, B.; Ågren, J. Thermodynamic assessments of the Ni-Pt and Al-Ni-Pt systems. Calphad 2009, 33, 450-456. [CrossRef]

28. Sato, K. Magnetic nanoparticles: When atoms move around. Nat. Mater. 2009, 8, 924-925. [CrossRef] [PubMed]

29. Gan, L.; Rudi, S.; Cui, C.; Strasser, P. Ni-catalyzed growth of graphene layers during thermal annealing: Implications for the synthesis of carbon-supported Pt-Ni fuel-cell catalysts. ChemCatChem 2013, 5, 2691-2694. [CrossRef]

30. Zhang, L.; Shi, W.; Zhang, B. A review of electrocatalyst characterization by transmission electron microscopy. J. Energy Chem. 2017, 26, 1117-1135. [CrossRef]

31. Gan, L.; Heggen, M.; O'Malley, R.; Theobald, B.; Strasser, P. Understanding and controlling nanoporosity formation for improving the stability of bimetallic fuel cell catalysts. Nano Lett. 2013, 13, 1131-1138. [CrossRef] [PubMed]

32. Gan, L.; Heggen, M.; Rudi, S.; Strasser, P. Core-shell compositional fine structures of dealloyed $\mathrm{Pt}_{(\mathrm{x})} \mathrm{Ni}_{(1-\mathrm{x})}$ nanoparticles and their impact on oxygen reduction catalysis. Nano Lett. 2012, 12, 5423-5430. [CrossRef] [PubMed] 
33. Zhu, H.; Zhang, S.; Huang, Y.X.; Wu, L.; Sun, S. Monodisperse $\mathrm{M}_{(\mathrm{x})} \mathrm{Fe}_{(3-\mathrm{x})} \mathrm{O}_{4}(\mathrm{M}=\mathrm{Fe}, \mathrm{Cu}, \mathrm{Co}, \mathrm{Mn})$ nanoparticles and their electrocatalysis for oxygen reduction reaction. Nano Lett. 2013, 13, $2947-2951$. [CrossRef] [PubMed]

34. Deepchand, V.; Abel, F.M.; Tzitzios, V.; Hadjipanayis, G.C. Chemical synthesis of L1 $1_{0}$ Fe-Pt-Ni alloy nanoparticles. AIP Adv. 2018, 8, 056210. [CrossRef] 